\title{
Parkland Agroforestry of Ethiopia; Key to Production, Productivity, Biodiversity Conservation and Climate Change Mitigation: A Review
}

\author{
Solomon Estifanos Bekele \\ School of Natural Resources Management and Environmental Sciences, College of Agriculture and Environmental Sciences, \\ Haramaya University, Haramaya, Ethiopia \\ Email:solestifa@gmail.com
}

How to cite this paper: Estifanos, S. B. (2018). Parkland Agroforestry of Ethiopia; Key to Production, Productivity, Biodiversity Conservation and Climate Change Mitigation: A Review. Open Journal of Forestry, 8, 472-488.

https://doi.org/10.4236/ojf.2018.84030

Received: July 11, 2018

Accepted: September 16, 2018

Published: September 19, 2018

Copyright $\odot 2018$ by author and Scientific Research Publishing Inc. This work is licensed under the Creative Commons Attribution International License (CC BY 4.0).

http://creativecommons.org/licenses/by/4.0/

\section{Open Access}

\begin{abstract}
Compiled information on parkland agroforestry tree species in relation to diversity, tree management options and the challenges of the system is important for production and productivity, and biodiversity conservation through availing the required information which in turn has an implication to the sustainability of the system and climate change mitigation. So, the aim of this review paper is to compile information on parkland agroforestry practices of Ethiopia, particularly: on tree species diversity, their roles, management options available and challenges of the practice. Parkland agroforestry which is a system practiced by many local populations comprises the large part of agricultural landscapes in Ethiopia and is very important in different aspects such as; for food security, microclimate amelioration, economic benefits, environmental protection, household energy, household utensils, cultural values, traditional medicines, and fodder. There are many indigenous multipurpose tree species scattered on farmlands in Ethiopia, and the common one includes: Millettia ferruginea, Cordia africana, Ficus vasta, Ficus sur, Croton macrostachyus and Faidherbia albida. However, nowadays these trees are facing challenges like: expansion of exotic trees in the expense of the native ones, expansion of cash crops through removal of the parkland trees from the farm area, climate change, land shortage and tenure system which require high emphasis for the production and productivity as well as sustainability of the system especially, in this era of climate change; hence this system is one of climate change mitigation options.
\end{abstract}

\section{Keywords}

Climate Change, Diversity, Parkland, Management Practices, Tenure System, Soil Fertility 


\section{Introduction}

Domestication of soil improving trees for enhancing the productivity of soil through a combination of selected trees and food crops on the same farm field is the major reason for practicing agroforestry land use systems (ICRAF, 2000) and hence, an agroforestry system is an age-old tradition in Ethiopia (Jama \& Zeila, 2005).

Forests are important natural resources that are contributing to ecology, rural livelihoods, national economies and international wealth. As a result, the destruction of forests is seen as a cause of environmental degradation, loss of biodiversity, climate change, and poverty. They are also recognized as a factor in climate change mitigation and adaptation, environmental stabilization and a source for local and national development (Bongers, 2010).

In order to provide more emphasis to the sector in Ethiopia, the "Forest Development, Conservation and Utilization Proclamation 542-2007" has been developed (FDRE, 2007) and again updated to a proclamation no. 1065/2018 (FDRE, 2018). This policy targets to address the demand for forest products, enhance the national economy, reduce forest degradation and related environmental disasters, and encourage the development of forests while conserving and using remaining forests in a sustainable way (FDRE, 2007; FDRE, 2018).

The major reason for practicing agroforestry land use systems like parkland trees is the domestication of soil improving trees for enhancing soil productivity through a combination of selected trees and food crops on the same farm field (Kassa et al., 2010). Agroforestry parkland systems is defined as areas where scattered multipurpose trees characterized by the diversity of woody or often indigenous species occur on farmlands as a result of farmer selection and protection (Boffa, 1999), landscapes in which mature trees occur scattered in cultivated or recently fallowed areas (Badege \& Abdu, 2003) (see Figures 1-3).

Parkland agroforestry which is a system practiced for many local populations is very important for food security, microclimate amelioration, income generation and environmental protection, and is found at different corners of the world, primarily in the semi-arid and sub-humid zones of Africa (Boffa, 1999). Kindeya (2004) reported that agroforestry practice is an aged practice in the Ethiopian farming systems off which parkland trees comprise the large part of agricultural landscapes and it is also the most dominant agroforestry practice in the semi-arid and sub-humid zones of Ethiopia.

Parkland trees are used to satisfy the needs and demands of the households. Some of the major roles they play includes: heating, cooking, household utensils, cultural values, provision of pollen and nectar for honey production, construction of houses and handles of farm implements (Negash, 2007), traditional medicines (Boffa, 2000; CIFOR, 2005), economic benefits, fodder values, employment opportunities and contribute to regional and national economy (Abebe, 2005). 


\subsection{Statement of the Problem}

Parkland agroforestry has been practiced by many farmers in different corners of the country; Ethiopia for many years by traditional and cultural way of cultivation. Many scholars have carried out different researches in different parts of the country about parkland trees of Ethiopia, even though it is not sufficient. However, very little compiled information is available to the stakeholders at different levels. So, the target of this review paper is to review and compile datum available with regards to tree diversity of parkland agroforestry/scattered trees on farmland/trees on cropland, their roles, available management options and the challenges of the system.

\subsection{The Purpose of the Review}

The overall aim of this review paper is to compile information on parkland agroforestry of Ethiopia, specifically;

a) To review on tree species diversity of parkland agroforestry

b) To review on the roles of parkland agroforestry

c) To review on management options available for parkland trees

d) To review on Challenges of parkland agroforestry

\section{Parkland Trees}

Parklands also known as scattered trees/trees in croplands are a very common type of agroforestry system in the tropics and characterized by well known scattered trees on cultivated and recently fallowed lands (Raj \& Lal, 2014) which is developed as a result of crop cultivation on a piece of land that became a permanent activity. Such a system of integrating tree species into farmlands provide productive, protective and socio-economic as well as religious roles that can improve the livelihoods of the society, especially for smallholder farmers in the developing or underdeveloped world suffering from hunger, poverty, and malnutrition (Raj \& Lal, 2014).

Trees are integrated in rural livelihood systems in order to satisfy people's demands (Wiersum, 2004; Cedamon et al., 2005), and trees in farming systems particularly provide directly consumable products as well as generate income and enhance the local ecological situation such as through soil improvement and their effect on micro-climate (Arnold, 1997). Analyzing the intensity with which trees are integrated into farm fields, taking into account the purpose, location, and density of trees, a division can be made into six different categories ranging between scattered trees on non-arable or fallow land and tree plantations (Arnold, 1997). These categories as modified by (Bongers, 2010) from Arnold (1997) are: a). trees on non-arable or fallow land: naturally regenerated trees on land without crops or grass, b). scattered trees in the arable land: naturally regenerated trees on cropland, c). trees growing in home gardens: mostly planted trees around the home area, d). trees growing in boundaries: planted trees as boundaries for demarcation of, or within, fields or to serve the protective purpose, e). intercropping of trees: planted trees on cropland, together with crops, 
and f). mono-cropping of trees: planted trees on cropland, without crops.

Agroforestry parkland systems are mainly cropland areas with dispersed trees (often indigenous) and mostly trees from the remnants of natural forests. Among the characteristics of traditional agroforestry parklands are the diversity of tree species they contain and the variety of products and uses. Boffa (1999) reported that parklands investigated so far in sub-Saharan Africa are proven to compose high species diversity i.e. often 40 - 50 woody species. These parkland trees generate and provide favorable micro-climates (through shade especially) and buffer extreme conditions (through acting as windbreaks). Parklands are found dominantly in the semi-arid and sub-humid zones of West Africa, but it doesn't mean that they are limited to.

\section{Tree Species Diversity in Parkland Agroforestry of Ethiopia}

Diversity is one of the most important community attributes that mainly includes two different aspects of vegetation; species richness and evenness that used to compute species richness (Zhang et al., 2012). Species richness is the number of species per a given area and is the simplest measure of diversity and does not consider differences in species relative abundance whereas; species evenness or the similarity in species relative abundance in a community is the relative abundance of species to all species or an even distribution of individual species (Zhang et al., 2012).

Different studies have been carried out on tree species diversity of parkland agroforestry at different localities in Ethiopia. For example, a study at Abreha Weatsebeha watershed of Tigray region that resulted in 1.12 and 0.41 of Shannon diversity and evenness respectively (Guyassa \& Raj, 2013), a study in Oromia region at East Shewa zone (Endale et al., 2017) with a finding of 2.43 and 0.31 of Shannon diversity and evenness respectively, a study carried out in the rift valley at Beseku, Arsi Negelle that reported Shannon diversity of 2.22 and evenness of 0.64 (Tolera, 2006). Additionally, Bongers (2010), on his research found 570 and 420 trees per ha respectively in Dirama and Dobi of Meskan District, Guyassa and Raj (2013) on a study conducted at Tigray region recorded 15 tree species on croplands, Endale et al. (2017) found 77 tree species on farmlands on the study conducted at semi-arid east Shewa, Gizachew et al. (2015) reported 16 tree species on parklands of Hawassa zuria, Tolera (2006) recorded 32 tree species on farmlands on Arsi Negelle and many more. This reviled that the roles of parkland agroforestry systems from the point of biodiversity conservation is very high and pertinent especially in conserving the indigenous tree species (Figures 1-3).

Trees found in farm fields do not recreate forests (Arnold, 1997) but do contribute to landscape based biodiversity (Boffa et al., 2005) like the realities in most parts of Ethiopia. Specific characteristics of tree species are very important for selection of species to be planted on to the farmland following certain criteria 


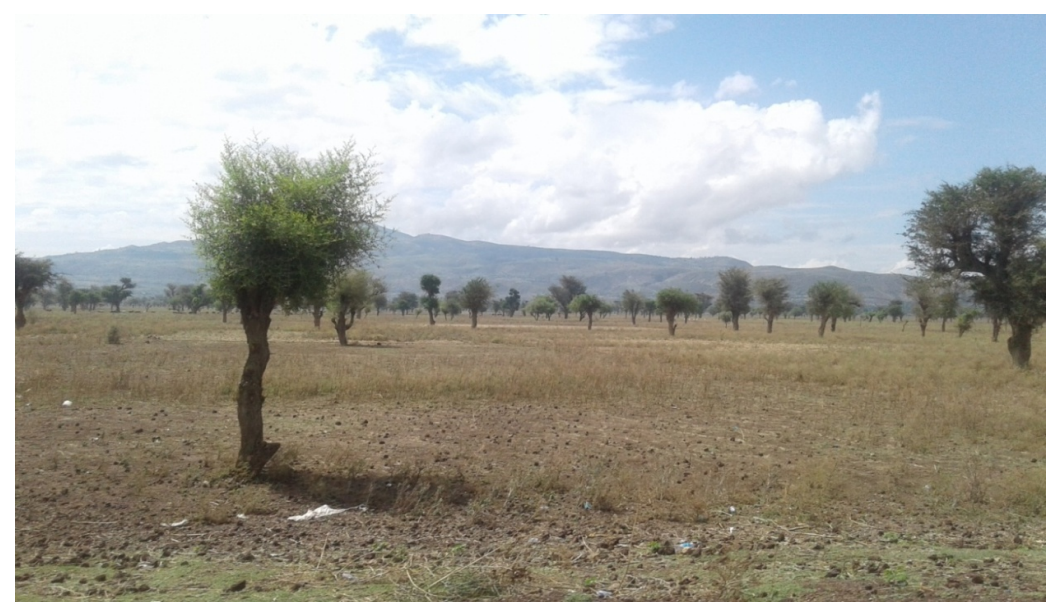

Figure 1. Faidherbia albida parkland trees around Olenchiti town, Ethiopia (by Solomon Estifanos, 2018).

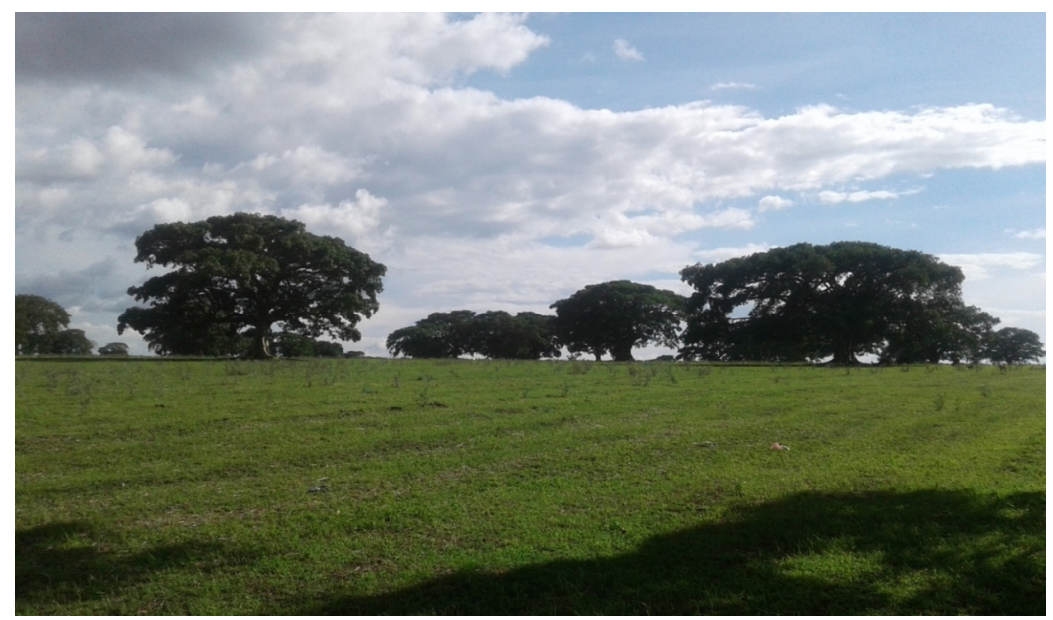

Figure 2. Ficus vasta parkland trees around Arsi Negelle, Ethiopia (by Solomon Estifanos, 2018).

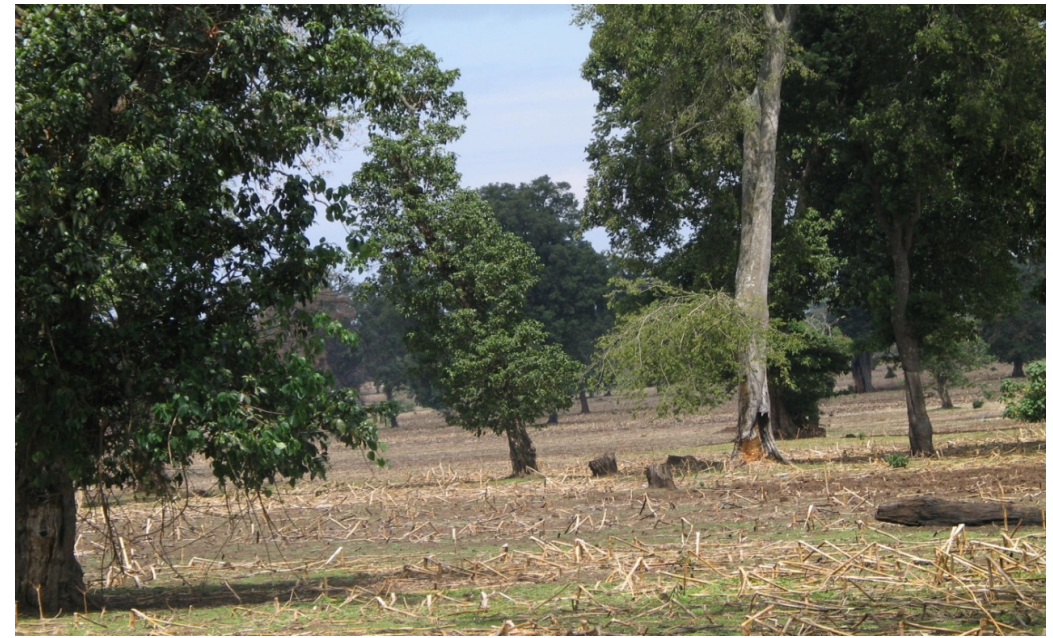

Figure 3. Celtis africana, Podocarpus falcatus and Prunus africana parkland tree species in Arsi Negelle, Ethiopia (Tolera, 2006). 
ranging between the utility, drought resistance nature of the species, compatibility with crop elements and potential for improvement of soil fertility (Bannister \& Nair, 2003; Roothaert \& Franzel, 2001). The selection is also influenced by a mixture of biophysical factors and social objectives (Long \& Nair, 1999). Furthermore, it depends on household characteristics, differences in ethnicity of the population (Boffa, 1999) and the local perceptions on the values of the trees. But in a general way, multipurpose trees (multipurpose trees are those tree species that are grown to provide more than one significant products or services being practiced on the farmland) (Raj \& Lal, 2014) are often selected as they can meet multiple demands while investments are overall low (Bongers, 2010).

Generally, the Ethiopian parkland includes exotic and indigenous trees off which the common indigenous parkland trees on croplands include: Millettia ferruginea, Cordia africana, Ficus vasta, Ficus sur, Croton macrostachyus and Faidherbia albida which are located at different densities and localities depending on different factors, and under different management options in a way that it contributes to the cereal crops beneath them. This trees could be the remnants of the natural stand or it could be plantations but in Ethiopia mostly the remnant of natural forests are very common (Figures 1-3) which might be totally lost if this systems were not there.

\section{Roles of Parkland Agroforestry}

Trees are most often integrated for their productive, protective and socio-economic and cultural roles for individual use within the farm fields (Wiersum, 1996). However, these are inseparable and very much interrelated for the productivity and sustainability of the system as a whole.

\section{a) Productive Roles}

Productive roles of the system refer to the production of one or more products for food, manure, timber, shelter, fodder, fuelwood, and the like (Raj \& Lal, 2014) which are mainly production of goods required to meet the basic needs of the society.

Parkland trees, contribute to livelihood strategies (Dawson et al., 2014) in different mechanisms like, production diversification (farmers can offset crop failures), forage feed for livestock (Atangana et al., 2014; Mekonnen et al., 2009) that enables the producer to include animals in their agricultural system thus creating additional income diversification and food for times when crop harvest is low, farm tools, fuelwood, construction materials, fruit and medicine (Guyassa \& Raj, 2013; Gizachew et al., 2015; Endale et al., 2017; Raj, 2016). Faidherbia albida; the most researched agroforestry species in Ethiopia improves barley productivity (Ernstberger, 2016; Hadgu et al., 2009), improves maize productivity (Gizachew et al., 2015; Poschen, 1986), 56\% yield increment of Sorghum under Faidherbia albidain Ethiopiaas compared to yields outside the tree canopy (Poschen, 1986; Bekele-Tesemma, 2007a) and 14\% increment in yield of Sorghum grain under Cordia africana parkland trees as compared to farmlands without trees in Burkina Faso (Boffa, 2000). 


\section{b) Protective Roles}

The roles that are considered as protective gives more emphasis to sustainability of the systems by the ecosystem services such as climate amelioration, reduction of loss of soil moisture, nitrogen fixation and soil fertility improvement, reducing wind and soil erosion, provision of shelter and shade, soil stabilization and conservation, biodiversity improvement, increment of aesthetic value, flood control, pest control etc. (Raj \& Lal, 2014).

The pressure of human population which resulted with intensified agriculture and reduced following period's consequently resulted in soil fertility problem in many farming systems throughout the tropics including Ethiopia.

The domestication of soil improving trees commonly known as multipurpose trees for enhancing soil productivity through a combination of selected trees and food crops on the same piece of a farm field is one of the reasons for practicing agroforestry (Kassa et al., 2010). Trees in general, prevent soil erosion which is a very serious problem nowadays in many corners of the country, as their perennial root networks stabilize the soil and are able to recover nutrients through pumping from deeper soil layers (Atangana et al., 2014; Bekele-Tesemma, 2007a) that are not easily accessible by the cereal crops (it is a means of attaining sustainable agricultural production and managing land resources (Bekele-Tesemma, 2007a)), for conservation, shade and fencing (Guyassa \& Raj, 2013; Gizachew et al., 2015). The research done by Asfaw and Agren (2007) stated that in southern Ethiopia Cordia africana has significantly more nutrients in the topsoil underneath its canopy, improves soil fertility, and soil and water conservation (Gizachew et al., 2015) and soil quality (Gelaw et al., 2015), improves soil and water conservation, soil fertility, and provide shade (Endale et al., 2017), improves some soil properties under their canopy as compared to the adjacent open lands (Gindaba et al., 2005; Yadessa et al., 2001).

Furthermore, Sileshi (2016) reported that Faidherbia albida parklands modify soil moisture availability through increased infiltration, fallen leaves of Faidherbia albida is commonly used as a fertilizer in farming systems (Tekalign et al., 1991), soil moisture content is significantly higher under Faidherbia albida tree as compared to outside the canopy of the trees (Hadgu et al., 2009), fixes nitrogen, improves the moisture status of the soil through uplifting of the underground water to the upper soil surface (Bekele-Tesemma, 2007a).

Additionally, Bayala et al. (2014) and Atangana et al. (2014) reported that parklands reduce the risk of climate change to small holders. This is because trees accumulate $\mathrm{CO}_{2}$ (which is the most predominant GHG) in their biomass (Raj, 2016) and in doing so, not only helps in climate change mitigation (due to an increased sequestration of carbon) but also climate change adaptation (due to the creation of more favorable microclimates on agricultural fields) which is also true to Ethiopian parkland agroforestry systems. It is an established fact that despite the climate changes mitigation (GHG reduction), there is a more pressing need to cope with the impact of climate change (adaptation). SO, with this regard, the trees in farmland provide shade for crops found beneath their canopy. 
Table 1. Some common indigenous parkland trees to Ethiopia and their common roles (compiled from Tolera, 2006; Gizachew et al., 2015; Ernstberger, 2016; Asfaw \& Agren, 2007; Hadgu et al., 2009; Bekele-Tesemma, 2007b; Hailu et al., 2000; Ashagrie et al., 1998; Yadessa, 1998; Bongers, 2010).

\begin{tabular}{|c|c|c|c|c|c|c|c|c|c|c|c|c|c|c|}
\hline \multirow{2}{*}{ Species Name } & \multicolumn{14}{|c|}{ List of benefits they render } \\
\hline & SD & $\mathrm{BF}$ & sc & BH & $\mathrm{CI}$ & $\mathrm{CM}$ & FT & FR & FD & FW & MC & PW & SF & TM \\
\hline Acacia abyssinica & & & $\sqrt{ }$ & & & $\sqrt{ }$ & $\sqrt{ }$ & $\sqrt{ }$ & & $\sqrt{ }$ & & & $\sqrt{ }$ & $\sqrt{ }$ \\
\hline Acacia etbaica & $\sqrt{ }$ & & $\sqrt{ }$ & & & $\sqrt{ }$ & & $\sqrt{ }$ & & $\sqrt{ }$ & & & & \\
\hline Acacia lahai & $\sqrt{ }$ & $\sqrt{ }$ & $\sqrt{ }$ & & $\sqrt{ }$ & $\sqrt{ }$ & & $\sqrt{ }$ & & $\sqrt{ }$ & & & & \\
\hline Acacia senegal & $\sqrt{ }$ & $\sqrt{ }$ & $\sqrt{ }$ & & & & $\checkmark$ & $\sqrt{ }$ & & $\sqrt{ }$ & & & $\sqrt{ }$ & \\
\hline Acaciia seyal & $\sqrt{ }$ & $\sqrt{ }$ & $\sqrt{ }$ & $\sqrt{ }$ & & & $\sqrt{ }$ & $\sqrt{ }$ & & $\sqrt{ }$ & & & $\sqrt{ }$ & \\
\hline Afrocarpus falcatus & $\sqrt{ }$ & & & & $\sqrt{ }$ & $\sqrt{ }$ & & & & & $\sqrt{ }$ & $\sqrt{ }$ & $\sqrt{ }$ & $\sqrt{ }$ \\
\hline Albizia gummifera & $\sqrt{ }$ & $\sqrt{ }$ & $\sqrt{ }$ & & $\sqrt{ }$ & & $\sqrt{ }$ & $\sqrt{ }$ & & $\sqrt{ }$ & $\sqrt{ }$ & & $\sqrt{ }$ & $\sqrt{ }$ \\
\hline Balanites aegyptiaca & $\sqrt{ }$ & & $\sqrt{ }$ & & & & $\sqrt{ }$ & $\sqrt{ }$ & & $\sqrt{ }$ & $\sqrt{ }$ & $\sqrt{ }$ & & \\
\hline Celtis africana & $\sqrt{ }$ & & & & $\sqrt{ }$ & $\sqrt{ }$ & $\sqrt{ }$ & $\sqrt{ }$ & & $\sqrt{ }$ & & & & $\sqrt{ }$ \\
\hline Cordia africana & $\sqrt{ }$ & $\sqrt{ }$ & $\sqrt{ }$ & & $\sqrt{ }$ & $\sqrt{ }$ & $\sqrt{ }$ & $\sqrt{ }$ & $\sqrt{ }$ & $\sqrt{ }$ & & $\sqrt{ }$ & $\sqrt{ }$ & $\sqrt{ }$ \\
\hline Croton macrostachyus & $\sqrt{ }$ & $\sqrt{ }$ & $\sqrt{ }$ & & $\sqrt{ }$ & $\sqrt{ }$ & $\sqrt{ }$ & $\sqrt{ }$ & & $\sqrt{ }$ & $\sqrt{ }$ & $\sqrt{ }$ & $\sqrt{ }$ & \\
\hline Erythrina brucei & & $\sqrt{ }$ & $\sqrt{ }$ & $\sqrt{ }$ & $\sqrt{ }$ & & $\sqrt{ }$ & $\sqrt{ }$ & & $\sqrt{ }$ & $\sqrt{ }$ & & $\sqrt{ }$ & \\
\hline Faidherbia albida & $\sqrt{ }$ & $\sqrt{ }$ & $\sqrt{ }$ & & $\sqrt{ }$ & $\sqrt{ }$ & $\sqrt{ }$ & $\sqrt{ }$ & & $\sqrt{ }$ & & & $\sqrt{ }$ & \\
\hline Ficus sur & $\sqrt{ }$ & $\sqrt{ }$ & $\sqrt{ }$ & & $\sqrt{ }$ & $\sqrt{ }$ & $\sqrt{ }$ & $\sqrt{ }$ & $\sqrt{ }$ & $\sqrt{ }$ & & & $\sqrt{ }$ & $\sqrt{ }$ \\
\hline Ficus Vasta & $\sqrt{ }$ & $\sqrt{ }$ & $\sqrt{ }$ & & $\sqrt{ }$ & & $\sqrt{ }$ & $\sqrt{ }$ & & $\sqrt{ }$ & & & $\sqrt{ }$ & $\sqrt{ }$ \\
\hline Millettia ferruginea & $\sqrt{ }$ & & $\sqrt{ }$ & & & $\sqrt{ }$ & $\sqrt{ }$ & & & $\sqrt{ }$ & & & & $\sqrt{ }$ \\
\hline Prunus africana & $\sqrt{ }$ & & & & $\sqrt{ }$ & $\sqrt{ }$ & $\sqrt{ }$ & & & $\sqrt{ }$ & & & & \\
\hline
\end{tabular}

where; " $\sqrt{ }$ "represents the species renders that particular benefit, $\mathrm{SD}=$ Shade; $\mathrm{BF}=$ Bee forage; $\mathrm{SC}=$ Soil conservation; $\mathrm{BH}=\mathrm{Beehives} ; \mathrm{CI}=\mathrm{Cash}$ income; $\mathrm{CM}$ = Construction material; FT = Farm tool; FR = Fodder FD = Food; FW = Fuelwood; $\mathrm{MC}=$ Medicine; $\mathrm{PW}=$ Pole wood; $\mathrm{SF}=$ Soil fertility; $\mathrm{TM}=$ Timber.

Different scholars have carried out a study about the effects of parkland agroforestry systems onto soil organic matter and most of them reported that there is an increase of soil organic matter under the canopy of different tree species than the corresponding open areas (Mamo \& Zebene, 2017; Yadessa et al., 2001; Hailu, 1997; Ashagrie et al., 1999).

The study carried out on different agro-ecological zones of Ethiopia on the extent of Faidherbia albida by Hadgu et al. (2011) found that fertility improvement (95\%), soil moisture retention (90\%), rainwater infiltration (88\%), bee forage $(80 \%)$, and livestock feed $(88 \%)$. Kassa et al. (2010), on the study done in Tigray region, reported that Balanites aegyptiaca, which is another potential tree for parkland agroforestry systems, has shown an increase of Sorghum yields. Trees on parkland, especially, if they are leguminous species they possess the function of fixing atmospheric nitrogen in symbiosis with bacteria and offer potential benefits to agriculture, hence they increase nitrogen availability (Munroe \& Isaac, 2014). Nowadays more than 600 tree species worldwide are known to fix nitrogen (Raj \& Lal, 2014). 


\section{c) Socio-Economic and Cultural Roles}

As a system of an agroforestry, parkland trees are not only used for productive and protective function even if these are theoretically the two fundamental attributes of all agroforestry systems (Raj \& Lal, 2014) but also for their social, economic and cultural as well as religious functions, commonly known as multipurpose agroforestry systems (Raj \& Lal, 2014).

Rhamnus prinoides is used for preparing a local beverage "tella" (Bongers, 2010) which is used in cultural and religious ceremonies and family or other informal gatherings. Big old trees mostly Ficus species used for "Adbar"; large trees seen as a religious temple which should be worshipped and kept satisfied (Bongers, 2010) (even if the species selection varies from place to place and from culture to culture); its use is secret and people do hardly elaborate on the background and current practices of the rituals include a typical Ethiopian coffee ceremony at night with the coffee snacks and slaughtered animals, and worshiping of the tree by placing butter on the stem.

Through the sale of agricultural and tree products the income of the households who are the owners of the farms could also be increased (Bekele-Tesemma, 2007a) so that the society could lead a better lifestyle.

Many scholars have tried to collect the roles or values of indigenous trees scattered on farmlands through different approaches mainly through questionnaire and here under indicated in the table for some of them (Table 1), which is all round benefits that categorized into three as indicated above (see Section $4 \mathrm{a}$, $\mathrm{b}$ and $\mathrm{c})$.

\section{Management of Parkland Trees}

Farming situations are widely recognized as an important factor influencing tree management practices of trees that are integrated within the farm fields (Arnold, 1997). Trees have a different value in diverse farming systems whether farms are mainly subsistence or market-oriented, and are therefore integrated to a varying extent within farm fields. The farming system is the main factor that is influencing tree utilization and management practices (Bongers, 2010). As compared to what is known about the crop and livestock components of agroforestry systems and practices, very little is known about existing parkland tree management practices, about farmers' perceptions of the roles of parkland trees and of different parkland tree outputs in meeting their needs and production objectives, and about the challenges farmers face that limit their potential to develop parkland tree resources within their farming systems.

Parkland trees management is a mechanism of controlling the tree-crop competition in farm fields hence selection and management of the species incorporated influences the success of the system. Management of trees is important to ensure the sustained return of mulch or leaf fodder and light shade through the application of pollarding, topping and pruning managements which should be done in early summer or at the end of the dry season (Kindeya, 2004). It is very 
important to understand tree management practices in a forest area and on private farm fields so that we can aim to enhance the cover on a certain area. To do so, it is crucial to understand management practices from the context of household livelihood strategies and farmers' opinion on the values of trees (Zubair \& Garforth, 2006). Tree management practices are often based on years of experiences of the farmers (Roothaert \& Franzel, 2001) which need to be understood very carefully and, it is an area where the interaction between trees and peoples is clearly observed.

Tree management practices are carried out in order to enhance and secure the trees' function now and in the future and are interdependent with tree utilization which is the final target. The research results of different scholars such as Arnold \& Dewees (1995), Nair (1993) and Abebe (2005) indicated that tree management practices have dual purposes i.e. reducing light competition with the undergrowth and provision of usable products to the farmers. The farm size, farmers age and wealth status are factors influencing tree planting activities (Schuren \& Snelder, 2008), as are the environmental conditions influencing actual growth and survival of trees related to specific tree characteristics (De Jong, 2001; Bannister\& Nair, 2003), which is true to Ethiopia as well.

There are different alternatives to management practices for agroforestry parklands and the major one constitutes pollarding, lopping of side branches (Negash, 2007), pruning (Gizachew et al., 2015), watering, plant protection and fertilizing (Guyassa \& Raj, 2013), root pruning (Bayala et al., 2013), coppicing (Raj \& Lal, 2014). Pollarding helps to reduce excessive shading whereas; lopping is to allow the mother trees to grow taller without casting heavy shade over the crops below (Bekele-Tesemma, 2007a). Thinning also carried out on parklands when the crowns of two or more adjacent trees started to close and caste heavy shade; however, it is not a common practice. Pruning of parkland agroforestry tree species retained in crop fields is meant for reducing the effect on crops, getting fodder for animals, and collecting wood to be used for fencing and firewood (Guyassa \& Raj, 2013).

Overall, the major reason behind parkland trees management is to maximize the benefits out of the system. Otherwise, parkland trees can compete with crops for different resources such as; for light, water and nutrients and decrease crop yield especially, when density and size of trees are high (Miller \& Pallardy, 2001).

\section{Challenges of Parkland Agroforestry}

Parkland trees are also known as scattered trees on farms are integral parts of smallholder farming systems in Ethiopia. Despite their substantial economic and ecological roles, these trees have received disproportionately little scientific attention in Ethiopia (Badege \& Abdu, 2003). The policy makers lack knowledge, not only of the benefits of agroforestry; notably, the income earning capacity of tree products and the soil enhancing services they provide as well, but also of the negative impacts of conventional agricultural and forestry production methods which is a monoculture. In most of the communities, a common belief is that 
introducing trees into fields will negatively affect the growth of agricultural crops (FAO, 2013), which is a blind generalization, but in reality, it depends on the species incorporated into the system, the management options applied for, and the like. However, most studies conducted indicated that the presence of trees on farms significantly increased the income and productivity of the land.

Regardless of the importance of agroforestry parklands, few quantitative data are available to assess trends in the condition of these systems in terms of density, age composition, and spatial extent. In general, tree densities in rural landscapes and parklands have significantly declined in past decades, especially since the droughts of the 1970s of Ethiopia, and they are characterized by a predominance of old trees and sometimes alarming lack of regeneration (Boffa, 2000). The other challenge that is significantly hampering the parkland trees is the expansion of exotic trees in the expense of the native ones which has its own consequence on to the biodiversity of the system and then to the country in large. With this regard, Tolera (2006) on his study conducted at Arsi Negelle Districts of Ethiopia recorded 32 tree species on croplands and all of them are indigenous species and this is an indication that the parklands are the remnants of the natural stands and the system is also a virgin/unchanged which is very much appreciated. Bongers (2010) reported that the number of trees on farmlands are becoming decreasing from time to time and is also true to the native trees as well.

However, other scholars have found out that the exotic trees are becoming common on parklands of Ethiopia. For example, Gizachew et al. (2015) reported $25 \%$ of the trees found on parklands are exotic trees on a study conducted at Hawassa Zuria District, Molla \& Kewessa (2015) on their study carried out at Dollo Menna District found out that $15 \%$ of parkland trees are exotic tree species, a study conducted in Gununo Watershed reported 31\% of the species are exotic (Bajigo \& Tadesse, 2015), Endale et al. (2017) on the study conducted at semi-arid parts of east Shewa has found 30\% of the species recorded are exotic species, Guyassa and Raj (2013) has recorded a 13.3\% of exotic tree species on the study carried out in Tigray region. So, this is an indication about the trends of the exotic tree species (farmers are planting exotic species with important economic roles they play, example; different Eucalyptus species) expansion into the croplands in the expense of the native trees.

Under the current pressure from land fragmentation and environmental and societal change, many Ethiopian smallholders are in the process of transforming their farming strategy towards market-oriented mono-cropping to meet their needs for household food security and income. The crops that are expanding in the form of cash crops on a mono-cropping approach include; Catha edulis, Coffea arabica, and Sugarcane and they are influencing parkland agroforestry systems negatively. This is again directly related to population pressure which in turn has linkage to the land shortage. In line with this, the investigation by En- 
dale et al. (2017) at East Shewa, revealed that tree species diversity is influenced by land-holding size. Additionally, Schuren and Snelder (2008) indicated that the size of farm, wealth status, and age of the farmers are also factors that influence the activities of tree incorporation to farmlands, besides the environmental factors that have direct linkage to specific tree characteristics. Furthermore, trees choice in a farm system also depends on household characteristics, the differences in ethnicity of the population and the local perceptions of the values of trees (Boffa, 1999).

Climate change has also its own negative impact on parkland trees because as climate change it is true the species also change; this, in turn, results in a change of the system. This is because what is a problem to the environment is common affects the parkland agroforestry practices as well. This is because an agroforestry system could play an important role in mitigating climate change hence, it sequesters more atmospheric carbon in plant parts and soil than the conventional mono-cropping farming system (Mulhollem, 2018).

Worede (1997) reported that in Ethiopia smallholder farms are under pressure as a result of intensification (includes use of inorganic fertilizer and Eucalyptus plantation for different uses (Hadgu et al., 2009)) and agro-ecosystem simplification which could be serious threat to the sustainability of agricultural productivity with negative consequences like: soil erosion, water scarcity and soil fertility decline (Dejene, 2003; Shiferaw \& Holden, 2000).

\section{Tenure Systems in Agroforestry Parklands}

In most of developing countries, land tenure creates a gender imbalance in land ownership, hence, in both legal and customary practice, women and other vulnerable groups, who may need to grow more food through the development of agroforestry (like parkland trees), have limited access to land and resources (FAO, 2013) which is also true to Ethiopia. But in reality, trees on farm require stability and security of tenure rights than in other agricultural systems (FAO, 2013). This is because of the longer periods trees need as compared to annual crops through which farmers' testing, adaptation and eventually adoption of agroforestry technologies takes place.

In Ethiopia, all land is owned by the government and then allocated to the citizens, but in the past history, there have been regular reallocations in connection to political events. This has led to certain insecurity in terms of investing in one's farmland (Gebremedhin \& Swinton, 2003; Gebremedhin et al., 2003). So, farmers with insecure land rights are unable or unwilling to plant trees which take a longer time to provide a return out of it in their cropland in the form of parkland agroforestry systems. But the scientific findings indicate that the practices of tree planting are very much important in order to enhance the tree cover in the farm fields. So, the policy direction aiming to increase tree cover should take into account scattered trees found on farm fields. 


\section{Conclusion and Recommendation}

Parkland trees which are very common practice in Ethiopia are a very important resource for the production, productivity, conservation of biodiversity and other related benefits that are dependent on the existence of the system. These trees are diverse ranging from native to exotic ones and have different densities per hectare; the tree species vary from place to place depending on factors such as; interest of farmers, land size, agro-climatic condition, characteristics of the species etc.

Different but appropriate management of parkland trees is very much needed for the productivity of crops and soils which could be increased by the incorporation of an appropriate use of local biodiversity resources. There are many parkland trees used in different corners of the country: Ethiopia and the most common indigenous parkland trees found include: Faidherbia albida, Cordia africana, Croton macrostachyus, Millettia ferruginea, Ficus vasta, Ficus sur, Acacia etbaica and Acacia lahai.

There are different challenges to the parkland agroforestry practices of Ethiopia and some of them include: land shortage as a result of population pressure, expansion of market-oriented products, climate change, land tenure system and expansion of exotic tree species in the expense of indigenous and native ones.

The practices of tree planting are very much important in order to enhance the tree cover in the farm fields. As a result, the policy aiming to increase tree cover should not only concentrate on large areas covered with trees but also should take into account scattered trees and small tree patches found on farm fields. Hence, there are very limited studies found so far on parkland trees of Ethiopia; there is a need for more comprehensive analysis of the multiple benefits and services provided by parkland trees located on farmlands.

\section{Acknowledgements}

I extend my deep gratitude to Haramaya University for covering the publication fee of this review paper. I would also like to thank my wife Mrs. Bisrat Moges for all of her assistance. Special thanks will go to all who contribute in manuscript preparation in one way or the other.

\section{Conflicts of Interest}

The author declares no conflicts of interest regarding the publication of this paper.

\section{References}

Abebe, T. (2005). Diversity in Homegraden Agroforestry Systems of Southern Ethiopia (143 p.). PhD Dissertation, Wageningen: Wageningen Agricultural University.

Arnold, J. E. M., \& Dewees, P. A. (1995). Tree Management in Farmer Strategies: Responses to Agricultural Intensification. Oxford: Oxford University Press.

Arnold, M. (1997). Farming the Issues. In M. Arnold, \& P. A. Dewees (Eds.), Farms, 
Trees, and Farmers. Responses to Agricultural Intensification (pp. 3-11). London: Earthscan Publications Ltd.

Asfaw, Z., \& Ågren, G. I. (2007). Farmers’ Local Knowledge and Topsoil Properties of Agroforestry Practices in Sidama, Southern Ethiopia. Agroforestry Systems, 71, 35-48. https://doi.org/10.1007/s10457-007-9087-0

Ashagrie, Y., Olson, M., \& Mamo, T. (1998). Contribution of Croton Macrostachys to Soil Fertility in Maize-Based Subsistence Agriculture of Bure Area, Northwestern Ethiopia (pp. 232-234).

Ashagrie, Y., Tekalign, M., \& Olsson, M. (1999). Changes in Soil Chemical Properties under Scattered Croton macrostachyus Trees in the Traditional Agroforestry System in North-Western Ethiopia. Ethiopian Journal of Natural Resources, 1, 215-233.

Atangana, A., Khasa, D., Chang, S., \& Degrande, A. (2014). Tropical Agroforestry. Dordrecht: Springer Dordrecht Heidelberg London New York.

https://doi.org/10.1007/978-94-007-7723-1

Badege, B., \& Abdu, A. (2003). Agroforestry and Community Forestry for Rehabilitation of Degraded Watersheds in the Ethiopian Highlands. In S. Assefa, \& A. Lemi, (Eds.), Proceeding of EAF International Symposium on Contemporary Development Issues in Ethiopia. Addis Ababa: Western Michigan University.

Bajigo, A., \& Tadesse, M. (2015). Woody Species Diversity of Traditional Agroforestry Practices in Gununo Watershed in Wolayitta Zone, Ethiopia. Forest Research, 4, 155.

Bannister, M. E., \& Nair, P. K. R. (2003). Agroforestry Adoption in Haiti: The Importance of Household and Farm Characteristics. Agroforestry Systems, 57, 149-157. https://doi.org/10.1023/A:1023973623247

Bayala, J., Roméo, B. H., \& Sanou, J. (2013). Competition and Facilitation Related Factors Impacts on Crop Performance in an Agroforestry Parkland System in Burkina Faso. African Journal of Agricultural Research, 8, 5303-5310.

Bayala, J., Sanou, J., Teklehaimanot, Z., Kalinganire, A., \& Ouédraogo, S. J. (2014). Parklands for Buffering Climate Risk and Sustaining Agricultural Production in the Sahel of West Africa. Current Opinion in Environmental Sustainability, 6, 28-34. https://doi.org/10.1016/j.cosust.2013.10.004

Bekele-Tesemma, A. (Ed.) (2007a). Profitable Agroforestry Innovations for Eastern Africa: Experience from 10 Agroclimatic Zones of Ethiopia, India, Kenya, Tanzania, and Uganda. World Agroforestry Centre (ICRAF), Eastern Africa Region.

Bekele-Tesemma, A. (Ed.) (2007b). Useful Trees and Shrubs of Ethiopia; Identification, Propagation and Management for 17 Agroclimatic Zones (552 p.). Nairobi: RELMA in ICRAF Project.

Boffa, J. M. (1999). Agroforestry Parklands in Sub-Saharan Africa. FAO Conservation Guide, Rome.

Boffa, J. M. (2000). West African Agroforestry Parklands: Keys to Conservation and Sustainable Management. Unasylva, 51, 11-17.

Boffa, J. M., Turyomurugyendo, L., Barnekow-Lilles, J. P., \& Kindt, R. (2005). Enhancing Farm Tree Diversity as a Means of Conserving Landscape Based Biodiversity. Mountain Research and Development, 25, 212-217. https://doi.org/10.1659/0276-4741(2005)025[0212:EFTDAA]2.0.CO;2

Bongers, G. (2010). Dynamics in People-Tree Interactions in Farm Fields; Farmers' Perspectives in Meskan District, Ethiopia. Wageningen: Wageningen University.

Cedamon, E. O., Emtage, N. F., Suh, J., Herbohn, J. L., Harrison, S. R., \& Mangaoang, E. O. (2005). Present Tree Planting and Management Activities in Four Rural Communi- 
ties in Leyte Province, the Philippines. Annals of Tropical Research, 27, 19-34.

Center for International Forestry Research (CIFOR) (2005). Research That Matters (p. 68). Annual Report.

Dawson, I. K., Leakey, R., Clement, C. R., Weber, J. C., Cornelius, J. P., Roshetko, J. M., Vinceti, B., Kalinganire, A., Tchoundjeu, Z., Masters, E., \& Jamnadass, R. (2014). The Management of Tree Genetic Resources and the Livelihoods of Rural Communities in the Tropics: Non-Timber Forest Products, Smallholder Agroforestry Practices and Tree Commodity Crops. Forest Ecology and Management, 333, 9-21. https://doi.org/10.1016/j.foreco.2014.01.021

De Jong, W. (2001). Tree and Forest Management in the Floodplains of the Peruvian Amazon. Forest Ecology and Management, 150, 125-134. https://doi.org/10.1016/S0378-1127(00)00686-1

Dejene, A. (2003). Integrated Natural Resources Management to Enhance Food Security: The Case for Community-Based Approaches in Ethiopia. Environment and Natural Resources Working Paper No. 16, Rome: FAO.

Endale, Y., Abayneh, D., Mekuria, A., \& Catherine, M. (2017). Farmland Tree Species Diversity and Spatial Distribution Pattern in Semi-Arid East Shewa, Ethiopia. Forests, Trees and Livelihoods, 26, 199-214. https://doi.org/10.1080/14728028.2016.1266971

Ernstberger, J. (2016). Perceived Multifunctionality of Agroforestry Trees in Northern Ethiopia, a Case Study of the Perceived Functions and Associated Personal Values of Trees for Farming Households in Tigray. Master's Thesis, Alnarp: Agricultural Science/Agroecology, Swedish University of Agricultural Sciences.

FAO (2013). Advancing Agroforestry on the Policy Agenda: A Guide for Decision-Makers (37 p.). Agroforestry Working Paper No. 1. Rome: FAO.

FDRE (2007). Forest Development, Conservation and Utilization Proclamation. Proclamation No. 542/2007, Addis Ababa: Federal Democratic Republic of Ethiopia.

FDRE (2018). Forest Development, Conservation, and Utilization Proclamation. Proclamation No. 1065/2018, Addis Ababa: Federal Democratic Republic of Ethiopia.

Gebremedhin, B., \& Swinton, S. M. (2003). Investment in Soil Conservation in Northern Ethiopia: The Role of Land Tenure Security and Public Programs. Agricultural Economics, 29, 69-84. https://doi.org/10.1111/j.1574-0862.2003.tb00148.x

Gebremedhin, B., Pender, J., \& Ehui, S. (2003). Land Tenure and Land Management in the Highlands of Northern Ethiopia. Addis Ababa: Western Michigan University.

Gelaw, A., Singh, B., \& Lal, R. (2015). Soil Quality Indices for Evaluating Smallholder Agricultural Land Uses in Northern Ethiopia. Sustainability, 7, 2322-2337.

https://doi.org/10.3390/su7032322

Gindaba, J., Rozanov, A., \& Negash, L. (2005). Trees on Farms and Their Contribution to Soil Fertility Parameters in Bedessa, Eastern Ethiopia. Biology and Fertility, 42, 66-71. https://doi.org/10.1007/s00374-005-0859-2

Gizachew, Z., Tesfaye, A., \& Wassie, H. (2015). Ficus vasta L. in Parkland and Agroforestry Practices of Hawassa Zuria District, Southern Ethiopia. Ethiopian Journal of Natural Resources, 15, 1-14.

Guyassa, E., \& Raj, A. J. (2013). Assessment of Biodiversity in Cropland Agroforestry and Its Role in Livelihood Development in Dryland Areas: A Case Study from Tigray Region, Ethiopia. Journal of Agricultural Technology, 9, 829-844.

Hadgu, K. M., Garrity, D. P., Mowo, J., \& Sileshi, G. (2011). Current Extent of Evergreen Agriculture and Prospects for Improving Food Security and Environmental Resilience in Ethiopia. International Journal of Agricultural Sciences, 1, 6-16. 
Hadgu, K. M., Kooistra, L., Rossing, W. A. H., \& van Bruggen, A. H. C. (2009). Assessing the Effect of Faidherbia Albida Based Land Use Systems on Barley Yield at Field and Regional Scale in the Highlands of Tigray, Northern Ethiopia. Food Security, 1, 337-350. https://doi.org/10.1007/s12571-009-0030-2

Hailu, T. (1997). Effect of Melletia ferruginea on Soil Fertility and Growth Performance of Maize. M.sc. Thesis, SLU.

Hailu, T., Legesse, N., \& Olsson, M. (2000). Millettia ferruginea from Southern Ethiopia: Impacts on Soil Fertility and Growth of Maize. Agroforestry Systems, 48, 9-24. https://doi.org/10.1023/A:1006274912762

ICRAF (2000). Paths to Prosperity through Agroforestry. ICRAF's Corporate Strategy, 2001-2010. Nairobi: International Centre for Research in Agroforestry.

Jama, B., \& Zeila, A. (2005). Agroforestry in the Drylands of Eastern Africa: A Call to Action. ICRAF Working Paper No. 1, Nairobi: World Agroforestry Centre.

Kassa, H., Gebrehiwet, K., \& Yamoah, C. (2010). Balanites aegyptiaca, a Potential Tree for Parkland Agroforestry Systems with Sorghum in Northern Ethiopia. Journal of Soil Science and Environmental Management, 1, 107-114.

Kindeya, G. (2004). Dryland Agroforestry Strategy for Ethiopia. In The Drylands Agroforestry Workshop (p. 26). Nairobi: ICRAF Headquarters.

Long, A. J., \& Nair, P. K. R. (1999). Trees outside Forests: Agro-, Community, and Urban Forestry. New Forests, 17, 145-174. https://doi.org/10.1023/A:1006523425548

Mamo, D., \& Asfaw, Z. (2017). Status of Selected Soil Properties under Croton Macrostachyus Tree at Gemechis District, West Hararghe Zone, Oromia, Ethiopia. Journal of Biology, Agriculture, and Healthcare, 7, 8.

Mekonnen, K., Glatzel, G., \& Sieghardt, M. (2009). Diversity of Farm Forestry Tree and Shrub Species, and Their Socio-Economic and Soil Fertility Improving Roles in the Central Highlands of Ethiopia. Forests, Trees, and Livelihoods, 19, 167-184. https://doi.org/10.1080/14728028.2009.9752662

Miller, A. W., \& Pallardy, S. G. (2001). Resource Competition across the Crop Tree Interface in a Maize-Silver Maple Temperate Alley Cropping Stand in Missouri. Agroforestry Systems, 53, 247-257. https://doi.org/10.1023/A:1013327510748

Molla, A., \& Kewessa, G. (2015). Woody Species Diversity in Traditional Agroforestry Practices of Dellomenna District, Southeastern Ethiopia: Implication for Maintaining Native Woody Species. International Journal of Biodiversity, 2015, Article ID: 643031.

Mulhollem, J. (2018). Agroforestry Systems May Play Vital Role in Mitigating Climate Change. https://news.psu.edu/story/503502/2018/02/01/research/agroforestry-systems-may-pla y-vital-role-mitigating-climate-change

Munroe, J. W., \& Isaac, M. E. (2014). N-2-Fixing Trees and the Transfer of Fixed-N for Sustainable Agroforestry: A Review. Agronomy for Sustainable Development, 34, 417-427. https://doi.org/10.1007/s13593-013-0190-5

Nair, P. K. R. (1993). An Introduction to Agroforestry. Dordrecht: Kluwer Academic Publisher. https://doi.org/10.1007/978-94-011-1608-4

Negash, M. (2007). Trees Management and Livelihoods in Gedeo's Agroforests, Ethiopia. Forests, Trees and Livelihoods, 17, 157-168. https://doi.org/10.1080/14728028.2007.9752591

Poschen, P. (1986). An Evaluation of the F. albida-Based Agroforestry Practices in the Hararghe Highlands of Eastern Ethiopia. Agroforestry Systems, 4, 129-143.

https://doi.org/10.1007/BF00141545 
Raj, A. (2016). Role of Agroforestry in Climate Change Mitigation.

Raj, J. A., \& Lal, B. S. (2014). Agroforestry Theory and Practices. Jodhpur: Scientific Publishers.

Roothaert, R., \& Franzel, S. (2001). Farmers' Preferences and Use of Local Fodder Trees and Shrubs in Kenya. Agroforestry Systems, 52, 239-252. https://doi.org/10.1023/A:1011896921398

Schuren, S. H. G., \& Snelder, D. J. (2008). Tree Growing on Farms in Northeast Luzon (The Philippines): Smallholders' Motivations and Other Determinants for Adopting Agroforestry Systems. In D. J. Snelder, \& R. D. Lasco (Eds.), Smallholder Tree Growing for Rural Development and Environmental Services (pp. 75-97). Berlin: Springer. https://doi.org/10.1007/978-1-4020-8261-0_3

Shiferaw, B., \& Holden, S. T. (2000). Policy Instruments for Sustainable Land Management: The Case of Highland Smallholders in Ethiopia. Agricultural Economics, 22, 217-232. https://doi.org/10.1111/j.1574-0862.2000.tb00071.x

Sileshi, G. W. (2016). The Magnitude and Spatial Extent of Influence of Faidherbia albida Trees on Soil Properties and Primary Productivity in Drylands. Journal of Arid Environments, 132, 1-14. https://doi.org/10.1016/j.jaridenv.2016.03.002

Tekalign, T., Haque, I., \& Aduayi, E. A. (1991). Soil, Plant, Water, Fertilizer, Animal Manure and Compost Analysis. Plant Sciences Division Working Document No. B13, Addis Ababa: International Livestock Centre for Africa (ILCA).

Tolera, M. (2006). Woody Species Diversity of Agricultural Landscapes in Arsi Negelle District, Ethiopia: Implications for Biodiversity Conservation. M.Sc. Thesis, Hawassa: Wondo Genet College of Forestry, Hawassa University.

Wiersum, F. (1996). Forestry and Rural Development; Lecture Course F500-218. Wageningen: Wageningen University.

Wiersum, K. F. (2004). Forest Gardens as an "Intermediate" Land Use System in the Nature-Culture Continuum: Characteristics and Future Potential. Agroforestry Systems, 61, 123-134. https://doi.org/10.1023/B:AGFO.0000028994.54710.44

Worede, M. (1997). Ethiopian in Situ Conservation. In N. Maxted, B. V. Fordlloyd, \& J. G. Hawkes (Eds.), Plant Genetic Conservation: The in Situ Approach (pp. 290-301). London: Chapman and Hall.

Yadessa, A. (1998). Evaluation of the Contribution of Scattered Cordia Africana Lam. Trees to Soil Properties of Cropland and Rangeland Ecosystems in Western Oromia, Ethiopia. M.Sc. Thesis, Sweden: Swedish University of Agricultural Sciences.

Yadessa, A., Itanna, F., \& Olson, M. (2001). Contribution of Indigenous Tree to Soil Properties: The Case of Scattered Trees of Cordia africana Lam. in Cropland of Western Oromia. Ethiopian Journal of Natural Resources, 3, 245-270.

Zhang, H., John, R., Peng, Z., Yuan, J., Chu, C. et al. (2012). The Relationship between Species Richness and Evenness in Plant Communities along a Successional Gradient: A Study from Sub-Alpine Meadows of the Eastern Qinghai-Tibetan Plateau, China. PLoS ONE, 7, e49024. https://doi.org/10.1371/journal.pone.0049024

Zubair, M., \& Garforth, C. (2006). Farm-Level Tree Planting in Pakistan: The Role of Farmers Perceptions and Attitudes. Agroforestry Systems, 66, 217-229.

https://doi.org/10.1007/s10457-005-8846-Z 